\section{Kuwait after the invasion}

SIR - I have been teaching at the faculty of medicine, Kuwait University, since September 1978, when the university began its first intake of preclinical students. Since 1984, I have been associate professor of biochemistry.

I was in Kuwait at the time of the Iraqi invasion on 2 August and have only recently returned home following the decision of the Iraqi authorities to release all Western hostages. Although unable to leave Kuwait or Iraq. I was as a Canadian citizen able to travel relatively freely within Kuwait City and was thus able to visit the medical school on several occasions following the invasion. While I am sure that your readers have read the newspaper reports concerning the atrocities committed by the Iraqis in Kuwait (for many of which I have myself listened to firsthand accounts). I believe your readers, including among their number so many of the world's academic and scientific community, should know of the extensive looting and virtual extinction of the medical school.

During the period following the invasion, I was able to witness at first hand the wholesale removal of facilities and equipment. Among items removed were the entire library and major equipment as well as chemicals. The laboratories had been for the most part ransacked, with broken bottles and their contents littering the floors.

During conversations with former students (both Kuwaiti and other Arab nationals), I was informed that they had witnessed professors from Iraqi universities squabbling with each other over what items of equipment were to be despatched to their individual departments and laboratories. This behaviour goes far beyond the minimal compliance with the military authorities that might have been excusable on the grounds of personal danger.

At both undergraduate and graduate levels, the students have been devastated by the dismantling of the university. Undergraduate students have spent up to six years of study at the university and for many the prospects of their completing their studies after so many years of effort look very dim. For the postgraduate students, vital equipment, animals and results relating to their thesis work have been lost or destroyed, and the same of course applies to faculty members who have seen the irreversible loss of many years" work. In a cynical move, the Iraqi authorities have offered places to students to continue their education at Iraqi universities. Not only does this mean leaving their country, homes and families, but in addition, the offer is conditional on Kuwaitis renouncing their citizenship. For both Kuwaitis and non-Kuwaitis, there is every likelihood that after transferring to Iraq, they would be called upon to serve in the Iraqi armed forces.

After many years of dedicated effort by Kuwaiti and cxpatriate staff, the medical school had reached standards recognized by many internationally respected academics and scientists who had visited the faculty in various capacities including as external examiners. The destruction of the medical school is a tragedy not only for Kuwait but for the whole of the region. A time will come when the international academic and scientific community should consider what action they might take to ensure that those responsible for these deeds are compelled to assist in the restoration of the Kuwait University Medical School.

Freie Universität Berlin,

GARY BURNS

Institut für Virologie.

Nordufer 20, 1000 Berlin 65, Germany

\section{Radiation risks}

SIR - In assessing the decision to reduce the limits for annual radiation doses to radiation workers (Nature 348, 274; 1990), it is important to distinguish between regulatory wisdom, however developed, and scientific substance. Although the decision is based on some scientific evidence, it also relies on the linear hypothesis which assumes that the biological effects of high levels of radiation can be extrapolated linearly to zero dose.

While this hypothesis is convenient, its predictions correlate poorly with epidemiological data on the effect of exposure to low levels of radiation (that is, below 100 millisieverts, $\mathrm{mSv}$ ). There is no consistent evidence of any hazard due to radiation at these levels ${ }^{1.2}$ ); indeed, some data suggest that those irradiated have reduced risks. For instance, people living in areas with high background radiation tend to have a lower incidence of cancer $^{+}$, and the average lifetime of the Japanese bombsurvivors now exceeds that of other Japanese. The apparently increased risk of leukaemia in children of workers at the Sellafield nuclear reprocessing plant has not been corroborated, nor other explanations excluded (see Nature 343, 679; 1990). But the International Commission on Radiological Protection recently reduced the permissible limits for the public to $1 \mathrm{mSv}$, well below many natural background levels, and has now further reduced the limits for radiation workers below the levels at which any hazard has been demonstrated.

While accepting the desire to maximize the safety of the public, including those with occupational exposure to radiation, we question whether the long-term effects of these unrealistic radiation limits will be beneficial. The overall costs arising for compliance with the standards and from distortion of the roles of nuclear industries may be enormous.

F. C. G. SOUTHON

S. C. GANDEVIA

Institute of Neurological Sciences,

Prince Henry Hospital,

PO Box 233, Matraville, NSW 2036.

Australia

1. Webster E. W. Am. J. Radiol. 137, 647 (1981)

2. Trott, K. R. \& Streffer, C. in Radiation Exposure and Occu pational Risks, $61-74$ (eds. Scherer, E. et al. Springer. Berlin, 1990).

. Mettler, F. A. \& Moseley, R. D. Jr Medical Effects of Ionizing Radiation, 90 (Grune \& Stratton. London 1985)

Nambi, K. S. V. \& Soman. S. D. Health Phys. 59. 339 (1990).

Cameron. J. Am. Ass. of Physicists in Med. Newsletter 15 $3(1990)$.

\section{Romania rebuilds}

SIR-The leading article "Will recession become slump?" (Nature 348, 96; 1990) flatly states that "prices have also increased in Romania and Bulgaria, so far without much compensating freedom", implying that nothing in Romania has changed.

In Romania, civil liberties have taken major steps forward: the springing up of numerous uncensored publications, political discussion in the streets and public places, unfettered and open meetings of individuals and organizations, unhindered meetings between foreigners and Romanians and open party politics.

In response to the December Revolution and the freedoms arising from it, a group of eminent ecologists, engineers, doctors, lawyers and writers founded the first private university in Romania, the Ecological University of Bucharest. Classes began last fall, only nine months after the revolution. The faculty had planned for 1,200 students but the current enrolment is 1,700 . There are six full schools: natural sciences, engineering, medicine, law, physical education and moral ecology.

Like many educational institutions in Romania, the university needs current books and scientific equipment. Sampling and analytical equipment media (gas chromatographs, HPLCs, atomic absorption spectrophotometers with furnace, and the rest) and methodological manuals for environmental sampling and analysis are especially needed.

I should like to hear from anyone who can donate books and/or equipment. DEBORAH WaLlace

CBNS, Queens College,

Flushing, New York 11367, USA

- The aspirations of the Hungarianspeaking minority of Transylvania and the future of the Hungarian-language minority there are apparently not so cheerful. Editor Nature. 